\title{
ISSUE BRIEF \\ Massive Open Online Courses: Legal and Policy Issues for Research Libraries
}

Brandon Butler

\section{Executive Summary}

Massive Open Online Courses (MOOCs) raise significant legal and policy questions for research libraries, which are often asked to support the development of MOOC courses. These questions involve information policy concerns that are central to research libraries, including the proper application of fair use, the transition to open access as the default mode of scholarly publishing, and the provision of equal access to learning materials for students with and without disabilities. Where possible, research libraries should engage in conversations around MOOCs and promote their core values. By doing so, they will also promote the continuing vitality of libraries as partners in the educational mission.

\section{Introduction}

The advent of Massive Open Online Courses raises serious legal questions that in turn pose important and fundamental policy challenges for research libraries. As universities rush to find ways to add courses to emerging MOOC platforms, research libraries are being asked to take on new responsibilities (or new versions of old responsibilities) to support this new mode of teaching and learning. Adapting to these new demands will surely be challenging for research libraries, but rising to the challenge will better serve libraries than the alternative of being excluded from the MOOC conversation. To help research libraries meet the challenge, this white paper will: briefly describe the MOOC phenomenon and the roles libraries are taking on in support of MOOC courses; outline some of the legal issues that MOOCs raise for research libraries and strategies for facing these challenges in constructive ways; and briefly discuss the potential stakes for research libraries as they work to meet these challenges.

\section{What is a MOOC?}

A MOOC is an online course that is free and open to anyone who wants to register. The courses are designed for massive enrollment, and some have already attracted more than 100,000 students, though far fewer students typically finish MOOC courses than initially enroll. Prominent MOOC initiatives include for-profit start-ups like Udacity and Coursera, both started by professors at Stanford University, as well as open source, non-profit efforts like MITx and the related edX platform. Early courses have been focused on STEM subject areas like computer science, but MOOC providers are expanding into all academic areas. ${ }^{1}$ Where the well-established OpenCourseWare

\footnotetext{
${ }^{1}$ See Steve Kolowich, Princeton, Penn and Michigan to join the MOOC party, InSIDE HiGHER ED, April 18, 2012, http: / / www.insidehighered.com/news / 2012/04/18 / princeton-penn-and-michigan-join-moocparty (planned Coursera courses "include six courses in the humanities and social sciences, including
} 
movement makes raw materials for teaching and learning available openly online, MOOCs seek to go one step further by providing an online version of a complete course, with video instruction, online quizzes and forums to encourage student engagement, virtual office hours where professors engage with students, and graded assignments (using software or peer students to do the grading) to evaluate whether students learn from the course. While some MOOC courses may be offered in partnership with instructors as independent agents, this white paper will focus on MOOC partnerships at the institutional level, where libraries are most likely to be engaged.

So far no institution is offering academic credit for taking a MOOC, though some are offering certificates of participation, and others may offer more official credentials in the future, likely at a cost to students. At least one institution has said it will award transfer credit to MOOC students with certificates. ${ }^{2}$ Several have announced partnerships with testing centers to facilitate more reliable assessment and, eventually, credentialing of some kind. Although some of the leading MOOC providers are ostensibly for-profit, none have actually implemented a monetization strategy, though charging for credit seems to be the most likely strategy. MOOC providers seem to be following a Silicon Valley model of generating interest and excitement first, with business models to be developed later.

\section{How Are Research Libraries Involved in Supporting MOOC Courses?}

So far research libraries appear to be serving two related roles in support of the MOOC courses provided by their campuses. First, as always, these libraries are serving faculty by supporting their need for material to use in their lectures and to assign for students' independent reading. From images to essays to software, research libraries are helping faculty to identify and locate resources that are appropriate for their teaching needs. Second, and very closely related, research libraries have been asked to work with faculty and campus counsel to navigate the copyright issues raised by teaching in the open, online environment. Research libraries often have a reputation on campus as copyright experts, so they are being asked to work with faculty to determine whether it is necessary to seek permission to use a given work in the context of MOOC teaching, and where necessary, seek to secure permissions.

In some cases research libraries are facing significant challenges and delays in seeking licenses for uses that would have been considered fair use or otherwise exempt in the traditional teaching context. Some publishers, museums, and other content owners are asking extraordinarily high prices or refusing to license for MOOC teaching, citing the for-profit nature of the platforms as well as the unprecedented scale. Others are simply not responding to these requests. Campus counsel at one library has advised that fair use is not an option in the context of MOOCs. As a result, some faculty are becoming frustrated with the process of translating courses they've taught for years, and for

History of the World Since 1300, Introduction to Sociology, and Modern \& Contemporary American Poetry").

2 See Steve Kolowich, MOOCing Onsite, INSIDE HigHER ED, Sept. 7, 2012, http:/ / www.insidehighered.com/news / 2012/09/07/ site-based-testing-deals-strengthen-case-grantingcredit-mooc-students. 
which they've developed tried-and-true slides, handouts, and other materials, into MOOC offerings. Where possible, research libraries are also working to help faculty identify and locate alternative materials that are free of copyright constraints either because they are in the public domain or because they are made available under Creative Commons or analogous open licenses.

\section{Legal Issues Raised for Research Libraries}

Some of the key legal issues that MOOCs raise for research libraries revolve around copyright and the use of copyrighted content in this new context, while others relate to open access and accessibility. Specifically, MOOCs raise legal questions in four main areas:

- use of copyrighted works in instructional materials such as online lectures or modules (the equivalent of traditional classroom teaching);

- assignment of copyrighted works for outside reading (the equivalent of assigned texts and course reserves);

- copyright status of materials generated by faculty for use in MOOC courses (including video lectures, course modules, and other supporting materials);

- applicability of the notice-and-takedown provisions of the Digital Millennium Copyright Act; and

- accessibility of MOOC courses for learners with disabilities.

\section{Use of Copyrighted Works in Instruction}

Teachers have always used copyrighted content in the course of their teaching, and it is well established that special license or permission is rarely required for such uses in the context of a traditional, physical classroom. Section 110(1) of the Copyright Act exempts display or performance of a work in the context of face-to-face teaching from copyright protection (so long as the copy used is lawfully made, so far as the teacher is aware). Section 107 of the copyright act, which codifies the fair use doctrine, makes explicit mention of "teaching (including multiple copies for classroom use)" as the kind of use that should be protected by that flexible doctrine. The familiar four-factor fair use analysis will typically look favorably on teaching uses, as will the modern method of analyzing uses on the basis of transformativeness, described in more detail below. The combination of specific protection in Section 110(1) and flexible protection in Section 107 have rightly given educators a sense that the classroom is a place where they can typically use third-party content in support of their pedagogy without permission or payment. ${ }^{3}$ Some materials used in classroom teaching may be subject to license

\footnotetext{
${ }^{3}$ It should be noted that one purported source of guidance, the 1976 "Agreement on Guidelines for Classroom Copying in Not-For-Profit Educational Institutionswith respect to books and periodicals," should no longer be considered useful or reliable. These privately negotiated guidelines have never had the force of law, and their self-described "minimum...standards" have too often been treated as the outer
} 
agreements (slides from licensed art databases, for example), but such licenses typically provide for traditional teaching as a permitted use. Similarly, material licensed under Creative Commons Non-Commercial licenses will apply comfortably to non-profit teaching, but may not be as amenable to use in the context of for-profit MOOC instruction.

The defining attributes of MOOCs, together with the for-profit nature of some leading MOOC providers, make them different from the traditional classroom in ways that could call into question the assumption of legitimate use, whether based on a statutory exemption or the terms of an applicable license. The application of these exceptions and licenses will need a careful reexamination in the MOOC context.

A threshold question for both Section 107 and Section 110 is whether MOOC teaching can be considered "non-profit." The answer is determinative for Section 110(1) and (2), which only apply to the teaching activities of "non-profit educational institution[s]." Obviously the partner universities satisfy this criterion, but do they retain that character when they act in partnership with for-profit MOOC providers? The answer is not clear. I spoke with two staff members at two different Coursera partner institutions who suggested the MOOC partnership may be more like for-profit publishing than nonprofit teaching, an analogy that colored their expectations about whether traditional teaching exceptions would apply.

Whether teaching activities on MOOC platforms are considered "non-profit education[]" is not determinative for Section $107 ;{ }^{5}$ fair use has been invoked with great success by for-profit entities as well as non-profit ones. However, non-profit educational uses are singled out under the first factor, which seems to favor such uses over commercial ones. As mentioned below, commercial uses must typically rely on a strong transformativeness argument, which requires thinking through how the use is different from the original intended use of the material, and whether it involves criticism, commentary, or other value-adding practices. One staff member suggested that slides used by instructors for "window dressing" (e.g., an attractive photo of the Parthenon shown in the background during a discussion of ancient civilization, but never specifically commented on or critiqued) would likely fail this transformative use test, and would need to be removed from MOOC presentations.

Assuming that Section 110 can apply to MOOC teaching (at least for the non-profit platforms), further analysis will be necessary. Section 110(1) exempts uses "in the course of face-to-face teaching activities...in a classroom or similar place devoted to instruction." ${ }^{\prime \prime}$ If "face-to-face...in a classroom" is read to mean "student and faculty are

limits of educational fair use. Judge Evans expressly rejected the Guidelines as a source of authority in the Georgia State University electronic reserves case, and her arguments on that point are persuasive. See Cambridge U. P. v. Patton et al., No. 1:08-CV-1425 ODE, slip op. at 56 ff. (N.D. Ga. May 11, 2012) (finding the Guidelines numerical caps are "not compatible with the language and intent of $\S 107$ " and their ban on repeated use across semesters is "an impractical, unnecessary limitation").

${ }^{4} 17$ U.S.C. $110(1)$ and $110(2)$

${ }^{5}$ See 17 U.S.C. 107; Campbell v. Acuff-Rose, 510 U.S. 569, 584 (1994) ("the mere fact that a use is educational and not for profit does not insulate it from a finding of infringement, any more than the commercial character of a use bars a finding of fairness.")

${ }^{6} 17$ U.S.C. $110(1)$ 
physically collocated in the same room," then the relatively straightforward exemption of Section 110(1) simply does not apply to online learning. There is some ambiguity in the statute, however, and "face-to-face" could be read more broadly, as could "similar place devoted to instruction." It is certainly true that evolving modes of communication and education have expanded notions of when people are 'face-to-face' and what sorts of places are 'dedicated to instruction.' In any event, the argument is less straightforward in the online context than it was in the traditional one.

Online displays and performances may fit more neatly into Section 110(2) of the Copyright Act, also known as the TEACH Act, which was passed to facilitate the use of copyrighted materials in distance and hybrid learning programs, including online learning. Unlike Section 110(1), the TEACH Act includes a series of requirements for educational use that reflect the concerns of rightsholders regarding the digital distribution of copyrighted works. Some of those requirements include:

- materials used cannot have been produced or marketed primarily for use in distance education;

- portions of dramatic works (e.g., plays and films) must be "reasonable and limited";

- access to content must, "to the extent technologically feasible," be limited to students enrolled in the course;

- technological protection measures (i.e., digital rights management (DRM)) should be used so that works displayed are only accessible during the class session and cannot be redistributed by students to others; and

- any DRM already used by rightsholders shouldn't be tampered with.

While the requirements of 110(2) are not impossible to satisfy, some institutions have found it difficult to design distance and hybrid education programs that conform to them. Institutions will have to examine whether their MOOC platforms make it feasible or even possible to ensure that displays and performances qualify for Section 110(2) protection.

Fair use, codified at Section 107 of the Copyright Act, has played a vital role in facilitating novel online uses of copyrighted material, and should be an important tool in the context of MOOCs. Education is very clearly singled out for favorable treatment under Section 107, both in the preamble ("purposes such as criticism, comment, news reporting, teaching (including multiple copies for classroom use), scholarship, or

\footnotetext{
${ }^{7}$ Again, the statute is ambiguous, here. A superficial reading may suggest that this language bars performance of entire works, but both legislative history and critical commentary suggest that streaming of entire films or plays may satisfy the "reasonable and limited" requirement under appropriate circumstances. See generally Jonathan Band, Brandon Butler, Kenneth D. Crews, and Kevin L. Smith, Issue Brief: Streaming Films for Educational Purposes at 5-6 (2010), http://www.arl.org/bm doc/ibstreamingfilms_021810pdf.pdf.
} 
research") and in the first factor ("the purpose and character of the use, including whether such use is of a commercial nature or is for nonprofit educational purposes"). Assuming materials are used in reasonable amounts, and that they are not materials created and marketed specifically for in-class use, a traditional four-factor analysis should be favorable for most instructional uses of educational content on MOOC platforms. The reported difficulty, even impossibility, of obtaining a license for use in MOOC teaching may also favor fair use, as it could be argued that there simply is not a functioning market for this type of use with respect to certain kinds of materials. ${ }^{8}$

In addition, use of copyrighted materials in instruction is susceptible to a favorable analysis under the dominant modern mode of fair use analysis, which asks whether the user has transformed the material she uses in order to create new insights, criticisms, and the like. ${ }^{9}$ Faculty who are using copyrighted material as the subject of criticism and commentary in their lectures should be strongly positioned to make this

transformativeness argument. Materials designed and marketed for in-class use, such as educational illustrations and films, would require a closer analysis, however, and may not qualify as fair use. Another consideration is that, in general, the more transformative a use, the less its commercial character weighs against it in the fair use calculus. If MOOC teaching is a for-profit activity, closer attention should be paid to the transformative rationales that could be applied to it.

In addition to the general strength of this use under both a traditional four-factor analysis and a modern transformativeness one, the advent of codes of best practice in fair use provides a third point of support. Several communities of practice have developed codes and statements describing appropriate fair use practices in the context of instruction, ${ }^{10}$ including the ARL Code of Best Practices in Fair Use for Academic and Research Libraries, the Visual Resources Association's Statement on the Fair Use of Images for Teaching, Research, and Study, ${ }^{11}$ and, perhaps most importantly, the Code of Best Practices in Fair Use for OpenCourseWare. ${ }^{12}$ The guidance in these documents helps practitioners understand what their communities regard as legitimate fair use, and at the same time provides judges with information about community norms, which

\footnotetext{
${ }^{8}$ This market failure argument was endorsed in the recent landmark decision validating mass digitization for search, preservation, and accessibility purposes. Authors Guild, Inc. v. HathiTrust, No. 11-CV-6351 (HB), slip op. at 21 (S.D.N.Y. Oct. 10, 2012) (crediting HathiTrust's argument that "the high costs will prohibit the formation of a viable market in the first place, and as a consequence there will be no one to buy the goods from.") (emphasis in original).

${ }^{9}$ Uses that satisfy these criteria are called "transformative," a term coined by Judge Pierre N. Leval in a 1990 law review article and later adopted by the Supreme Court in the Cambpell v. Acuff Rose case. See Pierre N. Leval, Toward a Fair Use Standard, 103 Harv. L. Rev. 1105 (1990), available at http:/ / docs.law.gwu.edu/facweb / claw / / LevalFrUStd.htm; Campbell v. Acuff Rose, 510 U.S. 569, 579 (1994). This mode of analysis is now the dominant mode of fair use reasoning in courts. See Neil Netanel, Making Sense of Fair Use, 15 Lewis \& Clark L. Rev. 715 (2011). Transformativeness played a central role in the HathiTrust case. See HathiTrust at 22 ("I cannot imagine a definition of fair use that would not encompass the transformative uses made by Defendants' [mass digitization project]....").

${ }^{10}$ The vast majority of these documents have been created in collaboration with professors Patricia Aufderheide and Peter Jaszi at American University, and are available at the Center for Social Media website, http:/ / www.centerforsocialmedia.org/fair-use.

${ }^{11}$ Available at http:/ / www.vraweb.org/ organization/pdf/VRAFairUseGuidelinesFinal.pdf.

${ }^{12}$ Available at http:/ / www.centerforsocialmedia.org/ocw.
} 
research suggests can be very influential to their decisions. Here are some example principles describing good practice in fair use for instruction:

"The investigation of preexisting works of authorship is an essential part of education, freedom of inquiry, and freedom of expression. Thus, this is a core example of fair use. Whatever the original informative or entertainment purpose that underlay the creation of the copyrighted material, it is being repurposed here as an object of commentary or other related discourse. This use of preexisting information or entertainment materials is a classic mode of advancing learning in the conventional faceto-face classroom, and it should be equally available in any OCW." Code of Best Practices in Fair Use for OpenCourseWare.

"For the reasons described in this statement, the reproduction and use of images for teaching - whether in face-to-face teaching, non-synchronous teaching activities, or non-course related academic lectures - should be consistent with fair use." VRA Statement on the Fair Use of Images for Teaching, Research, and Study.

"It is fair use to make appropriately tailored course-related content available to enrolled students via digital networks." ARL Code of Best Practices in Fair Use for Academic and Research Libraries.

Each of these principles is accompanied by a series of limitations, recommendations, and / or enhancements that are integral to the relevant principle and should not be read in isolation for purposes of actually applying them to a particular case. It should be clear from the principles alone, however, that the existing literature on fair use best practices provides substantial comfort for faculty teaching using electronic platforms.

The terms of use for licensed materials are typically far less flexible and open-ended than even Section 110, much less the fair use doctrine. Use of licensed material in MOOC teaching may well require a new or revised license in addition to the default agreement for campus access and use. As mentioned above, the applicability of Creative Commons Non-Commercial licenses may also be affected by the shift from traditional to MOOC teaching. One librarian working with faculty to design MOOC courses reported that publishers were asking much higher prices to license to MOOCs because of their apparent for-profit status, or else were uncertain how to proceed, as the lower, educational prices also seemed inappropriate.

\section{Assignment of Copyrighted Works for Outside Reading}

The assignment of copyrighted works for outside reading poses a more complex question for both traditional and MOOC teaching. While assigning outside reading is just as ubiquitous and well-established as instructional uses in the traditional classroom, student access to this material has not traditionally implicated copyright law, as this access was facilitated by students purchasing their own copies of assigned texts, by university libraries making copies available on physical reserve, or by the assembly and sale of paper coursepacks compiling excerpts and articles, with royalties paid by the seller and passed on to the student. Faculty for MOOC courses could 
certainly require that their students purchase textbooks and other materials, ${ }^{13}$ but that could undermine one of the key goals of many MOOC platform providers and participating institutions: offering a high-quality educational experience online that is completely free to the student. Daphne Koller, co-founder of Coursera, has said, "We do strongly urge instructors not to require any textbooks that cost money, since we want the courses to remain accessible even to students that cannot afford to purchase a textbook, including the many that don't even have a credit card." 14 To comply with this goal, faculty will have to find ways to provide outside study materials that are free of charge for their students.

One option that would avoid the student having to pay for access to copyrighted material would be for the institution to buy appropriate licenses for electronic materials, without passing the cost of the license along to students. Any such licenses may have to be negotiated from scratch, as existing bulk licenses may not be broad enough to support access for tens or hundreds of thousands of off-campus users without the same affiliation to universities as traditional faculty and students. Research libraries have extensive experience buying bulk licenses, and would be the natural purchasing agent for these new licenses. Experience teaches that such licenses are often quite expensive, however, and their prices can balloon over time. ${ }^{15}$ Some staff members reported that their institutions were considering collaboration with the Stanford rights-clearance project SIPX ${ }^{16}$ to obtain licenses.

Another option would be the use of materials made available for free or under an open access (OA) license such as the ones promulgated by Creative Commons. There are already companies and projects that create, publish, or otherwise make available open access textbooks and other learning materials. Flat World Knowledge, for example, makes textbook material available for free online, but makes money by charging for print, PDF, or ePub versions. For-profit publisher Elsevier has made one of its computer science textbooks available for free online in connection with an edX course taught by the book's author. ${ }^{17}$ Open access journals and repositories are also good sources for

\footnotetext{
${ }^{13}$ Indeed, textbook publishers and university presses are hopeful that purchases by MOOC students could be a significant new source of revenue. See Jennifer Howard, Publishers See Online Mega-Courses as Opportunity to Sell Textbooks, CHRON. OF HiGHER ED., Sept. 17, 2012, http: / / chronicle.com/article/CanMOOCs-Help-Sell / 134446/ ?cid=wc\&utm_source=wc\&utm_medium=en. However, other observers have suggested that MOOCs could replace textbooks because they offer a superior format for pre-packaged instructional material. See Will Oremus, The New Public Ivies, Slate, July 18, 2012, http:/ / www.slate.com/articles / technology / future_tense/2012/07/ coursera_udacity_edx_will_free_onli ne_ivy_league_courses_end_the_era_of_expensive_higher_ed_html (arguing that Coursera courses are "less like a dubious replacement for the college experience. Instead, they're more like a welcome replacement for another product: textbooks.").

${ }^{14}$ See Howard, supra n. 13.

${ }^{15}$ The situation seems to bear alarming resemblance to the electronic journals market, which is notoriously dysfunctional. See, e.g., Judith M. Panitch \& Sarah Michalak, The Serials Crisis, http:/ / www.unc.edu/scholcomdig/ whitepapers / panitch-michalak.html (2005) (describing the status quo of scholarly publishing as one where "knowledge created as a public good and at public expense is essentially being held hostage to interests that our not our own.").

${ }^{16}$ SIPX is an abbreviation for Stanford Intellectual Property Exchange. For more information, see http:/ / sipx.stanford.edu.

${ }^{17}$ See Steve Kolowich, Marketing to the MOOC Masses, INSIDE HigHER ED, Sept. 26, 2012, http:/ / www.insidehighered.com/news/2012/09/26/elsevier-partners-edx-provide-free-versions-
} 
scholarly reading assignments that do not require permission or payment. ${ }^{18}$ Close attention would have to be paid to the limitations, if any, on commercial or for-profit use of openly licensed material given the for-profit nature of some MOOC platforms.

A third option is to take advantage of Section 110(2), which allows the performance and display of copyrighted materials in e-learning, as discussed above. Although Section 110 is most directly applicable to the use of materials in the context of lectures, the text and legislative history make it clear that a professor need not be literally supervising the performance or display of covered works in real-time. Streaming films as assigned viewing for a film history class is an example of a possible 110(2)-sanctioned use. ${ }^{19}$ Section 110 may not cover uses of textual materials, however, as it applies only to "display" (i.e., of images) and "performance" (i.e., of audio-visual works, readings of plays, and the like). And, again, the for-profit status of some MOOC platforms may affect their eligibility for Section 110 protection.

Fair use provides an open-ended and flexible exception that would allow copying and distribution of material for educational reading, provided that it is sufficiently transformative or otherwise satisfies the statutory four-factor analysis. The ARL Code of Best Practices in Fair Use describes the consensus of the academic and research library community on this issue, including important limitations and enhancements to the fair use rationale. ${ }^{20}$ One important limitation is that these librarians do not believe there is a strong transformative rationale for posting readings from textbooks and other materials that are specifically created and sold for use in teaching the subject matter of the course (absent some special justification - e.g., use of textbooks as objects of criticism and commentary in a course on educational theory). This makes fair use an unlikely justification for sharing textbooks. ${ }^{21}$ That said, faculty assign a wide variety of different kinds of materials for study outside of class, and the Code can help faculty design and justify their assignments of non-textbook material consistent with the shared values of academic and research libraries. ${ }^{22}$

textbooks-mooc-students. The publisher hopes to use the free digital version, which is "static" and nondownloadable, to drive sales of the richer, more dynamic e-book version as well as the print version of the book. A portion of the revenue from student purchases of the book will be shared with edX. Coursera is reportedly working on a similar arrangement with Elsevier.

${ }^{18}$ The Textbook Affordability Project at the University of South Florida lists a wide variety of OA learning materials on its website, http: / / tap.usf.edu/faculty/open-access-textbooks / .

${ }^{19}$ See generally Band et al., supra n. 7 .

${ }^{20}$ See Principle One of the Code, available at http:/ / www.arl.org/pp/ ppcopyright/ codefairuse/code/one-supporting.shtml. The OpenCourseWare code urges caution in posting assigned reading in connection with online courses, and also singles out textbooks as unlikely to be proper subjects of fair use online. However, it concurs with the ARL Code that use of materials "not routinely licensed or available for sale for the intended amount of use" is more likely to be fair.

${ }^{21}$ Judge Evans also distinguished textbooks (though she cautioned against use of the term, preferring the general description "books intended exclusively for the use of students enrolled in a class") in her final order in the Georgia State electronic reserves case described below, saying that the reasoning in her May 11, 2012, opinion is limited to books with a wider audience than just students enrolled in a course. See Cambridge U. Press v. Becker, 1:08-cv-1425-ODE, slip op. at 5-7 (N.D. Ga. Aug. 10, 2012).

${ }^{22}$ Although the HathiTrust decision is not precisely on point, since it's focus is on mass digitization, at least one of its holdings may be useful: the court found that digitizing copyrighted works in order to 
Another possible source of authority on the proper scope of electronic course support is the district court's decision in the Cambridge U. Press v. Becker litigation, which is a dispute over the use of electronic course reserves and course management systems at Georgia State University. ${ }^{23}$ Judge Evans' decision and subsequent order in that case do describe a clear framework for fair use of scholarly books, but the utility of that decision remains to be seen. The publishers have appealed the decision to the 11th Circuit Court of Appeals, which may reverse or otherwise modify the district court's ruling, unsettling any decisions made on the basis of Judge Evans' opinion. Also, while the district court opinion is long and detailed, and may be persuasive to other judges, it is not binding precedent for them; any federal judge is free to disagree and rule differently. Even after the 11th Circuit issues its opinion, courts in other circuits will remain free to disagree. In view of these facts, extensive reliance on the GSU case is premature at this point.

\section{Ownership of Course Content}

As with any material that is created by faculty as part of their scholarship and teaching, the question could arise as to who owns the copyright in MOOC materials, ${ }^{24}$ the faculty as the original author, or the university under work-for-hire principles, or some other option ${ }^{25}$ At most universities, faculty members are assumed to own the works they create as researchers and teachers, with some caveats. Who will own the course materials provided to MOOC platforms? This will depend on the agreements between MOOC platform providers and the instructors and universities who partner with them. At least one provider leaves copyright ownership with the instructor or institution, asking only for a non-exclusive license to use the content. This seems like the most likely scenario, but is not a foregone conclusion.

The question of ownership may be especially interesting for institutions that have adopted an open access policy, such as the one in place at Harvard University, which automatically grants a non-exclusive license to the university for any faculty-prepared scholarly articles. ${ }^{26}$ Such licenses come into being immediately upon the creation of

make them accessible is a highly transformative fair use. See HathiTrust at 22. Given the commitment to accessibility that most MOOC providers seem to share, there could be ample room for fair use as a tool to ensure that materials are available in suitable formats to facilitate equal access.

${ }^{23}$ The full text of the decision is available here:

http:/ / www.nacua.org/documents/CambridgeUPress_v_Becker_051112.pdf. See also, Brandon Butler, ISSUE BRIEF: GSU Fair Use Decision Recap and Implications, May 15, 2012,

http:/ / www.arl.org/bm doc/gsu_issuebrief_15may12.pdf.

${ }^{24}$ Relatedly, there may be important questions of ownership as to the data generated as a result of a MOOC course-information about how students use the platform may be especially useful and interesting to scholarship in many fields. The library's interest in ensuring reasonable access to this data is on a par with its interest in the course materials generated by faculty. This may be a harder "ask," as MOOC platform providers stand to benefit financially from this data, as well.

${ }^{25}$ The University of Virginia, for example, claims ownership of faculty scholarship as an initial matter, but then cedes ownership back to faculty unless "significant University resources" are used in the creation of the work. See Ownership Rights in Copyrightable Material,

https: / / policy.itc.virginia.edu / policy / policydisplay?id=\%27RES-001 (last visited Sept. 20, 2012).

${ }^{26}$ For more information on this kind of open access policy, see Stuart Sheiber, Is the Harvard open-access policy legally sound?, Sept. 17, 2012, https:/ / blogs.law.harvard.edu/pamphlet/2012/09/17/is-theharvard-open-access-policy-legally-sound/. 
certain types of copyrightable work, preempting any competing license to a third party. Depending on its precise wording, ${ }^{27}$ such a policy could preserve the institution's right to make any course material developed for MOOCs available freely as OpenCourseWare or in any other medium they choose, even if the MOOC agreement purports to grant an exclusive license. That said, institutions interested in retaining the right to re-use course content created for MOOC teaching should pay close attention to the license agreements they sign with MOOC platform providers. This is much less of a concern for edX and its collaborators, as their intention is that all courses be available under some sort of open license in any event.

\section{Applicability Of The Notice-And-Takedown Provisions Of The Digital Millennium Copyright Act}

Section 512 of the Copyright Act, part of the Digital Millennium Copyright Act (DMCA), protects Internet service providers and other platform providers from liability for copyright infringement carried out by third parties using their services. This is the provision that protects YouTube, for example, from the potentially devastating responsibility of policing every video uploaded by its users. Educational institutions also invoke this protection against responsibility for the potentially infringing activities of students and other users of campus networks. In order to qualify for protection under Section 512, a service provider must meet certain requirements, including the obligation to take down allegedly infringing content in response to a valid takedown notice sent by a rights holder or its representative.

Some library staff working with MOOC platform providers report that at least one MOOC platform is interested in taking advantage of the Section 512 safe harbors. Specifically, this person was told that the MOOC platform would comply with the notice-and-takedown provision, taking material offline in response to an allegation of infringement. It would be the university's responsibility to provide alternative materials for the course, or else to issue a counter-notice under the DMCA requesting that the platform provider restore the content.

While Section 512 does provide very useful protection for a wide variety of online service providers, it is strange to think that it would apply to MOOC platforms. The safe harbors are meant to protect service providers who are in some sense at an arms length from their users; the infringing activities must be conducted at the direction of the user and the platform provider is meant to be a disinterested party merely providing a technological tool or resource to the user without regard to what the user then does with the platform. The relationship between MOOC platforms and their partner institutions seems much more intimate than that, with some MOOC platforms reserving the right to approve or reject course content based on their own requirements of quality. Also, Section 512(e) specifically exempts the teaching activities of faculty and

\footnotetext{
${ }^{27}$ The Model Policy promulgated by Stuart Sheiber, for example, would not cover MOOC materials, as it is limited to "scholarly articles." See Stuart Sheiber, A Model Open Access Policy, http:/ / osc.hul.harvard.edu/sites/default / files / model-policy-annotated_0.pdf. There is no reason in principle that a policy could not be expanded to cover teaching materials, though that may require new negotiations with faculty.
} 
graduate students from safe harbor protection, saying that institutions cannot disown their online posting of required or recommended instructional materials.

While a MOOC platform may choose to comply with the notice-and-takedown process described in the DMCA, it is not clear that they would actually qualify for the provision's protection. And by opening themselves up to the notice-and-takedown process, MOOC providers may be subjecting courses to capricious and inaccurate takedown requests. ${ }^{28}$ Research libraries will need to consider how best to cope with a MOOC partner who demands high quality material and at the same time takes no responsibility for that content when a rights holder files a DMCA complaint.

\section{Accessibility Issues}

The law requires educational institutions to provide access to educational opportunities to all students on an equal basis without regard to disability. This obligation is wellestablished: Section 504 of the Rehabilitation Act, passed in 1973, bars any educational institution receiving federal funds from discriminating against students with disabilities, requiring such institutions to provide equal opportunities to disabled students. The Americans with Disabilities Act (ADA) bars public colleges and universities from denying services, programs, or activities to disabled students, and prohibits private institutions from discriminating against disabled students, as well.

These obligations likely apply to university efforts on MOOC platforms, despite their being cutting edge or pilot programs. The US Department of Justice has aggressively pursued this issue with respect to early efforts to adopt e-readers in universities, warning institutions that use of non-accessible Kindles, even for pilot programs, would violate both Section 504 and the ADA. ${ }^{29}$

Providing accommodations may require copying and modifying copyrighted material adding captions to video or text descriptions to audio, converting images of text into machine-readable formats, and the like. These actions implicate copyright. Section 121 of the Copyright Act, also known as the Chafee Amendment, allows some copying to accommodate blind persons, and fair use provides an open-ended, flexible exception that could be applied to any effort to make works accessible. The HathiTrust decision strongly supports the application of both provisions to university and library accessibility efforts. In it, Judge Baer holds that the ADA "requires that libraries of educational institutions have a primary mission to reproduce and distribute their collections to print disabled individuals, making each library a potential 'authorized entity' under the Chafee amendment." ${ }^{\prime 30}$ Even where the Chafee Amendment does not

\footnotetext{
${ }^{28}$ The proliferation of bogus, often automated, takedown notices is well documented. See, e.g., Mike Masnick, Fox Issues DMCA Takedown To Google Over SF Chronicle Article... Claiming It Was The Movie 'Chronicle', TECHDIRT, May 29, 2012, http:/ / www.techdirt.com/articles/20120525/01520819073/foxissues-dmca-takedown-to-google-over-sf-chronicle-article-claiming-it-was-movie-chronicle.shtml. ${ }^{29}$ See US Dept. Justice, Joint “Dear Colleague" Letter: Electronic Book Readers, June 29, 2010, http:/ / www2.ed.gov/ about/ offices / list/ ocr/ letters / colleague-20100629.html; US Dept. of Education, Office of Civil Rights, Frequently Asked Questions About the June 29, 2010, Dear Colleague Letter, May 26, 2011, http:/ / www2.ed.gov/ about/ offices/list/ocr/ docs/dcl-ebook-faq-201105.pdf.

${ }^{30}$ See HathiTrust at 22-23.
} 
apply, HathiTrust found that making works accessible can be powerfully transformative, and thus a core fair use. Principle Five of the ARL Code expresses the strong consensus among librarians that this practice constitutes fair use. ${ }^{31}$

The responsibility to ensure MOOC content is accessible will likely be divided between the platform providers and the partner institutions. At least one provider describes in its agreement with partners explicitly how these responsibilities are to be divided, requiring that almost all material be accessible by default. ${ }^{32}$ Attorneys familiar with the contract say it shows an unusually strong commitment to accessibility.

\section{Strategic Considerations for Research Libraries}

The legal challenges described above do not arise in a vacuum; whether and how to use content in service of education within the bounds of copyright law is a fundamental policy concern for research libraries. Each legal challenge provides research libraries with an opportunity to advance some of the community's deepest and most longstanding policy commitments. As these libraries work with their parent and partner institutions, they should keep in mind the following strategic considerations.

\section{Fair Use Is an Essential Right for Libraries and Their Users}

Perhaps no part of the Copyright Act plays as central a role in library practice in the digital age as the fair use doctrine. ARL's experience in developing and promulgating the Code of Best Practices in Fair Use for Academic and Research Libraries has further confirmed the centrality of fair use to member libraries and their users. ${ }^{33}$ A defining feature of fair use is its sensitivity to facts about common practice; to repeat a popular cliché, fair use is like a muscle that can be strengthened with exercise, or it can atrophy with disuse. Consequently, libraries must confidently assert their fair use rights in each new domain of practice in order to ensure their long-term flourishing, or else risk the contraction of these rights if the doctrine is abandoned in the face of new challenges. Whether the issue is making accessible copies, designing rich and engaging lectures, or providing access to material for coursework, fair use should be a live option for supporting MOOC participation. Multiple best practice documents already support the application of fair use in this way. This does not mean that fair use will always apply in these situations, or that research libraries should not pay license fees or make other arrangements where appropriate. But the doctrine should always be on the menu of options available for meeting the legal and strategic challenges that research libraries face. Ruling fair use out of bounds preemptively in this new context is unnecessary and could adversely affect how the doctrine is applied to new, electronic platforms.

\footnotetext{
${ }^{31}$ See ARL Code, Principle Five, http: / / www.arl.org/pp/ppcopyright/ codefairuse/ code / fivereproducing.shtml.

32 The only element of accessibility that is not automatically 'baked in' to this particular agreement seems to be captioning of video lectures, which the platform provider does automatically for classes with more than 10,000 enrolled students but only "upon request by an End User with disabilities" for smaller courses.

${ }^{33}$ See, e.g., ARL Code at 2 (research on library community norms revealed "fair use is an essential component of copyright exemptions for librarians....").
} 


\section{"Set the Default to Open"}

The transition to open models of scholarship and education is an extraordinarily important development for research libraries that have consistently been at the vanguard of the open access movement. Research libraries are directly, dramatically, and adversely affected by the dysfunctional nature of traditional scholarly publishing, and at the same time these libraries know that new modes of scholarly communication can substantially reduce those dysfunctions. Convincing faculty to publish in open access outlets has been one of the great challenges to the open access transition, but a new strategy of adopting carefully crafted open access policies promises to guarantee that institutions can build open repositories of the scholarship created on their campuses in the future. ${ }^{34}$ This practice is part of what open access advocates have called "setting the default to open access," the theme for Open Access Week 2012 and the first recommendation of the Budapest Open Access Initiative on the occasion of its $10^{\text {th }}$ anniversary. ${ }^{35}$

MOOC courses are essentially a mode of scholarly publishing: they are authored by scholars, intended for use in education, and are subject to copyright protection and its associated limitations and exceptions. It makes sense, therefore, for research libraries to advocate for open access as the default status of MOOC course materials. Licenses with MOOC platform providers should be non-exclusive and subservient to any prior license granted to the university under an applicable open access policy. Open access policies should be reviewed to ensure that they apply to the kind of content created for MOOCs. Otherwise, research libraries could find themselves in the same regrettable position with respect to MOOCs as they have been with other scholarly publications: buying back resources that were created and supported at universities in the first place.

Relatedly, research libraries should encourage the use of open access materials in MOOCs wherever possible. As faculty work to create MOOC courses, some are already reportedly encountering trouble due to copyright restrictions on material they use for their teaching. While fair use should always be a potential solution, some material (such as textbooks and other works created and sold expressly for instructional use) will be difficult to use under a fair use rationale. Copyright issues are already leading to frustration among MOOC teaching faculty, and this provides a teachable moment for open access advocates. As faculty and staff work to navigate the difficult or impossible task of clearing necessary rights for copyright-encumbered materials, they may be more receptive to open access alternatives. In the process, they may be receptive to a broader discussion about the importance of making their own work (especially new work created for MOOC teaching) available on an open access basis so that they and their peers can use it in a variety of contexts without worrying about copyright.

\footnotetext{
${ }^{34}$ See Sheiber, supra n. 26 for more information about these institutional policies.

35 See http: / / www.openaccessweek.org (last visited Sept. 21, 2012); Ten years on from the Budapest Open Access Initiative: setting the default to open, http: / / www.soros.org/openaccess/boai-10recommendations (last visited Sept. 24, 2012) ("Every institution of higher education should have a policy assuring that peer-reviewed versions of all future scholarly articles by faculty members are deposited in the institution's designated repository").
} 
Finally, research libraries should work to ensure that all the information generated by MOOC teaching, including information about how students use the platform, can be collected and held by research libraries. This information is a valuable record of university activity, and may be of interest to a wide variety of research library users in the future. Data about student use of MOOCs could support new scholarship as well as helping to improve online education for future users.

\section{Accessibility Should Be "Baked In"}

Just as open access should be the default and automatic status of the content created or shared for MOOC teaching, accessibility should be 'baked in' to all the content that makes up a MOOC course. Research shows that retroactively making material accessible is much more difficult, more expensive and usually less useful to the print disabled than designing accessibly in the first place. Equitable access for all users by default is not just the most efficient course, nor is it merely a legal obligation; it is a core ethical obligation for libraries. And, as the HathiTrust case shows, the law will be extremely friendly to libraries taking steps to ensure fully accessible resources for all of their users. As new technologies make truly equitable access possible, it would be a tragic mistake to build platforms that needlessly perpetuate the challenges that old media posed for learners with disabilities. Research libraries are taking important steps to make accessibility a priority, and those efforts should extend to MOOC content.

\section{Conclusion - Stakes for Research Libraries}

It should be clear from the preceding discussion that libraries have a significant stake in the way their parent and partner institutions approach the MOOC phenomenon. In addition to the strategic concerns already described-keeping fair use on the table, protecting and extending open access policies, ensuring accessibility-research libraries have a more general stake where MOOCs are concerned, which is the continuing relevance of libraries and library collections to university teaching. Will materials in library collections be incorporated, by means of fair use or licensing, into MOOC courses? Will research librarians be trusted experts to whom MOOC instructors turn for help identifying and locating educational resources, whether owned or licensed? Will library values of openness and equal access hold sway, or will the novelty of the MOOC phenomenon lead institutions down a different path? If, as some believe, MOOCs are the future (or at least a significant part or indicator of the future) of university teaching, it is important that research libraries think strategically about how they support this new phenomenon in its formative stages. 